\title{
SIMULASI DATA ACQUISITION ALAT UJI FLIGHT CONTROL ACTUATOR PESAWAT MENGGUNAKAN SOFTWARE LABVIEW
}

\section{DATA ACQUISITION SIMULATION OF TEST EQUIPMENT AIRCRAFT FLIGHT CONTROL ACTUATOR USING LABVIEW SOFTWARE}

\author{
Decy Nataliana ${ }^{1}$, Usep Ali Albayumi ${ }^{2}$, M.Sheen Al-C Parawansa ${ }^{3}$, Arsyad Ramadhan Darlis ${ }^{4}$ \\ ${ }^{1,3,4}$ Teknik Elektro Institut Teknologi Nasional (ITENAS) Bandung \\ ${ }^{2}$ PT.Dirgantara Indonesia \\ $\underline{{ }^{1} \text { sheen.cautzar@gmail.com, }}, \underline{{ }^{2} \text { decyhari@gmail.com, }}{ }^{3}$ usep@gmail.com,,$\underline{\text { arsyaddarlis@gmail.com }}$
}

\begin{abstract}
Abstrak
Flight control system merupakan suatu sistem di pesawat udara yang digunakan untuk pergerakan pesawat di udara dari satu kondisi terbang ke kondisi terbang lainnya. Alat uji flight control system actuator pesawat ini untuk mengetahui beban yang diterima terhadap jarak dari pergerakan aktuator pesawat. Sistem akuisisi data dari alat uji flight control actuator berupa data beban dan jarak, serta pemberian PWM (Pulse Width Modulation). Data akuisisi menggunakan bantuan software Labview sebagai software untuk memprogram dan interface data akuisisi pada PC dan juga pada bagian hardware mekanikal menggunakan mikrokontroler arduino uno sebagai media untuk akuisisi data. DAQ alat uji flight control actuator pesawat dirancang menggunakan LabView yang telah direalisasikan, yaitu mampu menampilkan data berat yang diterima aktuator, yang berupa motor servo sebagai unit under test, dengan berat maksimum 2 $\mathrm{kg}$ serta mampu menampilkan data pergerakan unit under test dari pergerakan $3 \mathrm{~cm}-5 \mathrm{~cm}$, serta mampu menampilkan PWM yang diberikan pada unit under test saat bergerak maju sebesar 45, saat bergerak mundur 135 dan saat berhenti 90 .
\end{abstract}

\section{Kata Kunci : LabView, Arduino Uno, DAQ, Flight Control System, PWM}

\begin{abstract}
Flight control system is a system in aircraft that used to the movement of aircraft in the air from one condition to fly to other flight conditions. Testing instruments aircraft flight control actuator system is to determine the load received on the distance of the movement of aircraft actuators. Data acquisition system of test equipment flight control actuators in the form of a data load and distance, as well as the provision of PWM (Pulse Width Modulation). Data acquisition using Labview software as software for programming and data acquisition interface on the PC and also on the mechanical hardware using microcontroller as a medium for data acquisition. DAQ test equipment flight control actuator aircraft designed using LabView has been realized, which was capable to display the weight data that received by actuator, which is a servo motor as a unit under test, with a maximum weight of $2 \mathrm{~kg}$ and is capable of displaying the data movement unit under test on the movement of $3 \mathrm{~cm}-5 \mathrm{~cm}$, and capable to display PWM given to the unit under test while moving forward at 45, and moving backwards when stopped 135 and 90.
\end{abstract}

Keywords: LabView , Arduino Uno, DAQ, Flight Control System, PWM 


\section{PENDAHULUAN}

Data Acquisition System (DAQ) adalah sebuah proses pengambilan sampel sinyal yang mengukur kondisi fisik nyata (real) dan kemudian mengkonversi sampel yang telah dihasilkan menjadi nilai numerik digital yang dapat dimanipulasi pada komputer oleh operator, Sistem akuisisi data biasanya mengubah gelombang analog menjadi nilai digital untuk diproses lebih lanjut [1]. Data Acquisition System di flight control system (FCS) adalah suatu sistem di pesawat udara yang digunakan untuk manuver pesawat dari satu kondisi terbang ke kondisi terbang lainnya. Dalam flight control system diperlukan alat uji untuk ketahanan sistem aktuator yang akan digunakan pada pesawat serta jarak pergerakan pada sistem flight control actuator tersebut [2]. Pada umumnya di industri pembuatan pesawat memiliki alat uji flight control actuator dengan skala yang besar, jadi cukup rumit apabila ingin menerapkan sistem alat uji yang baru dan ingin mencoba sistem yang baru [3]. Sebelum alat uji flight control actuator dibuat dengan skala yang besar untuk jenis pesawat, maka pada penelitian ini penulis ingin merancang dan meralisasikan sebuah sistem alat uji flight control actuator untuk pesawat dengan skala yang lebih kecil. Berikut spesifikasi untuk alat uji flight control actuator skala kecil secara umum antara lain:

1. Unit under test yang dimana terdapat motor servo continous yang digunakan sebagai aktuator pesawat.

2. Sensor ping digunakan untuk mengetahui jarak saat aktuator bergerak.

3. Sensor load cell digunakan untuk mengetahui beban yang di terima oleh aktuator.

4. Limit switch digunakan untuk pembatas aktuator saat bekerja naik dan turun.

5. Solenoid valve $4 / 3$ untuk mengontrol saluran udara yang bertekanan menuju aktuator pneumatik(cylinder).

6. Pneumatic actuator digunakan untuk bergerak naik dan turun sehingga beban yang diberikan dapat terangkat

7. Control untuk mengolah data dan pengendali dari alat uji flight control actuator.

8. Computer untuk menampilkan data yang dikirim oleh controller yang berasal dari unit under test.

Skematik keseluruhan sistem alat uji flight control actuator yang digunakan dapat dilihat pada Gambar 1.

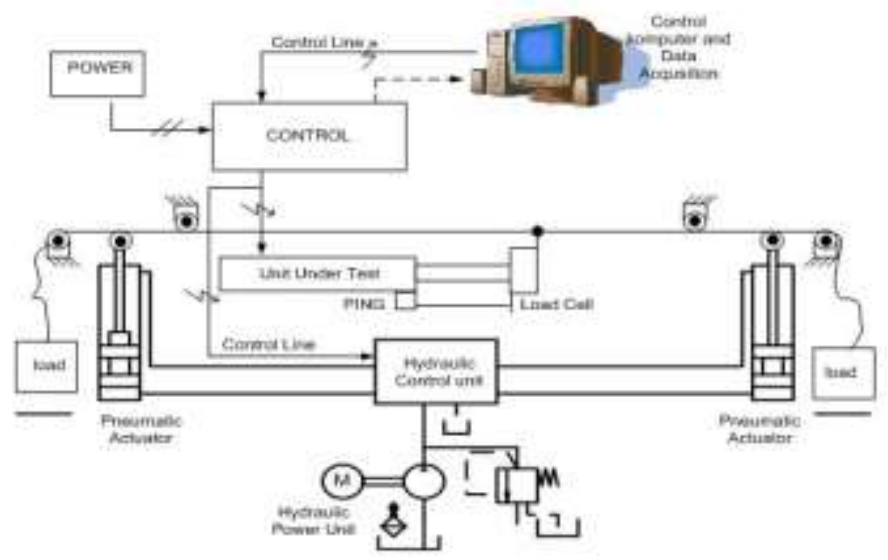

Gambar 1. DAQ alat uji flight control actuator

Menurut Didik, dalam aplikasi sistem pengendalian di industri, kebutuhan untuk pengambilan dan pengolahan data menjadi semakin komplek. Oleh karena itu, dibutuhkan suatu 
perangkat yang dapat menangani kebutuhan tersebut, salah satunya adalah dengan sistem akuisisi data. Sebuah alternatif modul DAQ yang dibuat dari mikrokontroler ATMEGA8535 yang dapat diakses menggunakan LabVIEW yang berkomunikasi secara dua arah menggunakan komunikasi serial. DAQ ini dapat mengakuisisi 8 saluran masukan dengan konversi ADC 10 bit dan 8 saluran keluaran dengan sinyal Kendali PWM. Pada pengujian hasil konversi ADC, nilai tegangan yang ditampilkan oleh LabVIEW dengan nilai tegangan pada sensor mempunyai RMSE sebesar 0,019 volt. Dalam pengujian plant PCT-09 didapatkan hubungan antara level yang ditampilkan pada LabVIEW dan level pada Plant PCT-09 mempunyai nilai RMSE sebesar 0,75mm. Sementara itu, sampling rate yang digunakan untuk menambahkan data dari plant sebesar 510 milidetik dan mempunyai sinyal kendali PWM dengan duty cycle sebesar 3,4 milidetik. Pada pengujian masukan digital, DAQ mempunyai frekuensi maksimum yang bisa diakuisisi sebesar 32,767 Hz [4,5].

Penelitian yang dilakukan Wenda menjelaskan tentang analisis data kecelakaan dan kegagalan sistem rudder yang telah berhasil di analisis yaitu, kegagalan pada sistem rudder merupakan jenis kegagalan flight control system, yang memiliki pengaruh kegagalan bersifat kata tropik dengan peluang kejadian $\leq 10-9$. Beberapa kecelakaan yang melibatkan kegagalan sistem rudder dikaji secara khusus untuk mendapatkan faktor-faktor yang sama (common) dan yang tidak dalam kejadian kecelakaan tersebut [6]. Berdasarkan beberapa kajian pustaka yang telah diambil sebagai referensi, maka pada penelitian ini penulis merancang dan merealisasikan DAQ untuk alat uji flight control actuator yang mampu mengetahui beban yang diterima oleh aktuator pesawat dan mampu mengetahui jarak dari pergerakan aktuator. Alat uji flight control actuator dikendalikan secara terpusat menggunakan mikrokontroler. Mikrokontroler yang digunakan adalah arduino uno yang telah diprogram menggunakan bahasa $C$. Penelitian ini membahas perancangan dan realisasi DAQ untuk alat uji flight control actuator dari aktuator pesawat yang bagaimana arduino dapat mengatur kerja alat uji flight control actuator dimulai pada saat aktuator bergerak hingga mampu mengangkat beban, serta menampilkan data berat dan jarak yang berasal dari aktuator saat bergerak.

\section{PERANCANGAN DAN REALISASI DAQ ALAT UJI FLIGHT CONTROL ACTUATOR}

\subsection{Gambaran Umum Sistem}

Gambaran umum DAQ alat uji flight control actuator ini digunakan untuk menampilkan, mengambil, mengumpulkan dan menyimpan data kedalam bentuk yang siap untuk diproses lebih lanjut. DAQ alat uji flight control actuator ini membutuhkan kontroller yang berfungsi mengontrol dari alat uji flight control actuator serta mengolah data yang selanjutnya di tampilkan data tersebut ke komputer dengan tampilan yang dibuat menggunakan software labview berupa data digital satuan jarak dan berat.

Alat kontrol yang digunakan menggunakan arduino uno yang berbasis atmega328 dengan diprogram menggunakan bahasa $\mathrm{C}$. Arduino uno ini akan dihubungkan dengan komputer, sehingga tampilan data tersebut dapat terlihat. Cara kerja akuisisi data alat uji flight control system actuator yang telah dirancang dan direalisasikan diharapkan mampu bekerja sesuai dengan yang diharapkan. Berikut ini tahapan sistem yang harus dilakukan pada akuisisi data alat uji flight control system actuator pesawat terbang:

1. Kondisi awal jika alat dihidupkan adalah pembacaan tranduser, tranduser tersebut berupa sensor ping dan load cell.

2. Kondisi berikutnya adalah ketika kedua sensor tersebut aktif maka sensor akan mengirim data berupa data analog yang kemudian dikirim ke kontroller arduino uno .

3. Apabila data berupa data analog maka data tersebut di konversi kedalam data digital. 
4. Hasil konversi data dari arduino . Selanjutnya data tersebut dikirim kembali ke komputer untuk di tampilkan dan disimpan.

\subsection{Perancangan dan Realisasi Perangkat Keras (Hardware)}

Spesifikasi akusisi data alat uji flight control actuator yang dirancang dan direalisasikan harus mampu melakukan beberapa proses yaitu:

1. Mampu menghubungkan antara arduino uno dengan Labview dengan komunikasi usb.

2. Mampu menampilkan data dari sensor ping ke tampilan Labview yang terdapat pada computer data tersebut berupa satuan jarak .

3. Mampu menampilkan data dari sensor load cell ke tampilan LabView yang terdapat pada komputer data tersebut berupa satuan berat .

4. Mampu mengubah data sensor ping yang berupa satuan jarak kedalam bentuk grafik.

5. Mampu mengubah data sensor load cell yang berupa satuan berat kedalam bentuk grafik.

6. Mampu menyimpan data yang dihasilkan dari sensor ping dan load cell dalam bentuk microsft excel.

Berdasarkan spesifikasi akusisi data alat uji flight control actuator yang diinginkan, maka blok diagram sistem yang dirancang dapat dilihat pada Gambar 2.

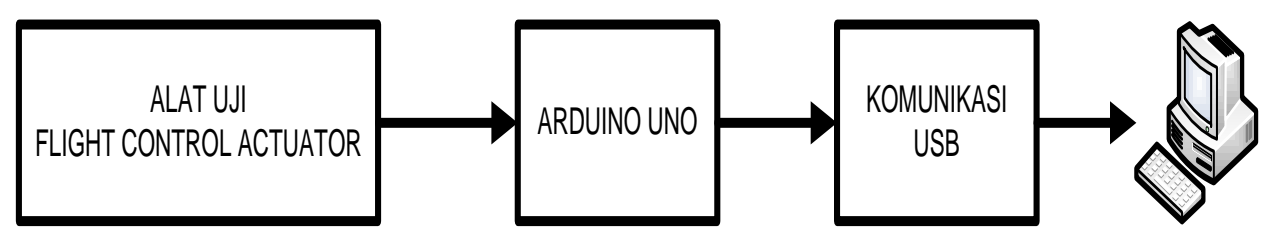

Gambar 2. Blok diagram sistem

Berdasarkan blok diagram data akuisisi keseluruhan pada Gambar 2 dapat dilihat bahwa arduino uno terdiri dari 2 input dan 1 output. Berikut ini akan dijelaskan mengenai masing-masing fungsi dari input maupun output sistem yang dirancang berdasarkan blok diagram di atas.

1. Load cell berfungsi untuk mengetahui beban yang di terima oleh aktuator. Hasil pembebanan tersebut diasumsikan bahwa beban tersebut merupakan tekanan dari udara saat pesawat berada di udara.

2. PING berfungsi untuk mengetahaui jarak, dimana jarak yang diukur adalah jarak dari pergerakan aktuator saat melakukan pergerakan maju dan mundur.

3. Arduino uno merupakan pengendali utama dari akusisi data alat uji flight control actuator. Penggunaan arduino ini karena penggunaan yang sederhana serta pemograman yang digunakan cukup mudah [7]

4. Komunikasi usb

5. Komputer berfungsi menampilkan data yang telah di proses oleh arduino uno dengan tampilan pada software Labview.

Gambar 3 merupakan realisasi dari keseluruhan perancangan perangkat keras alat uji flight control actuator. 


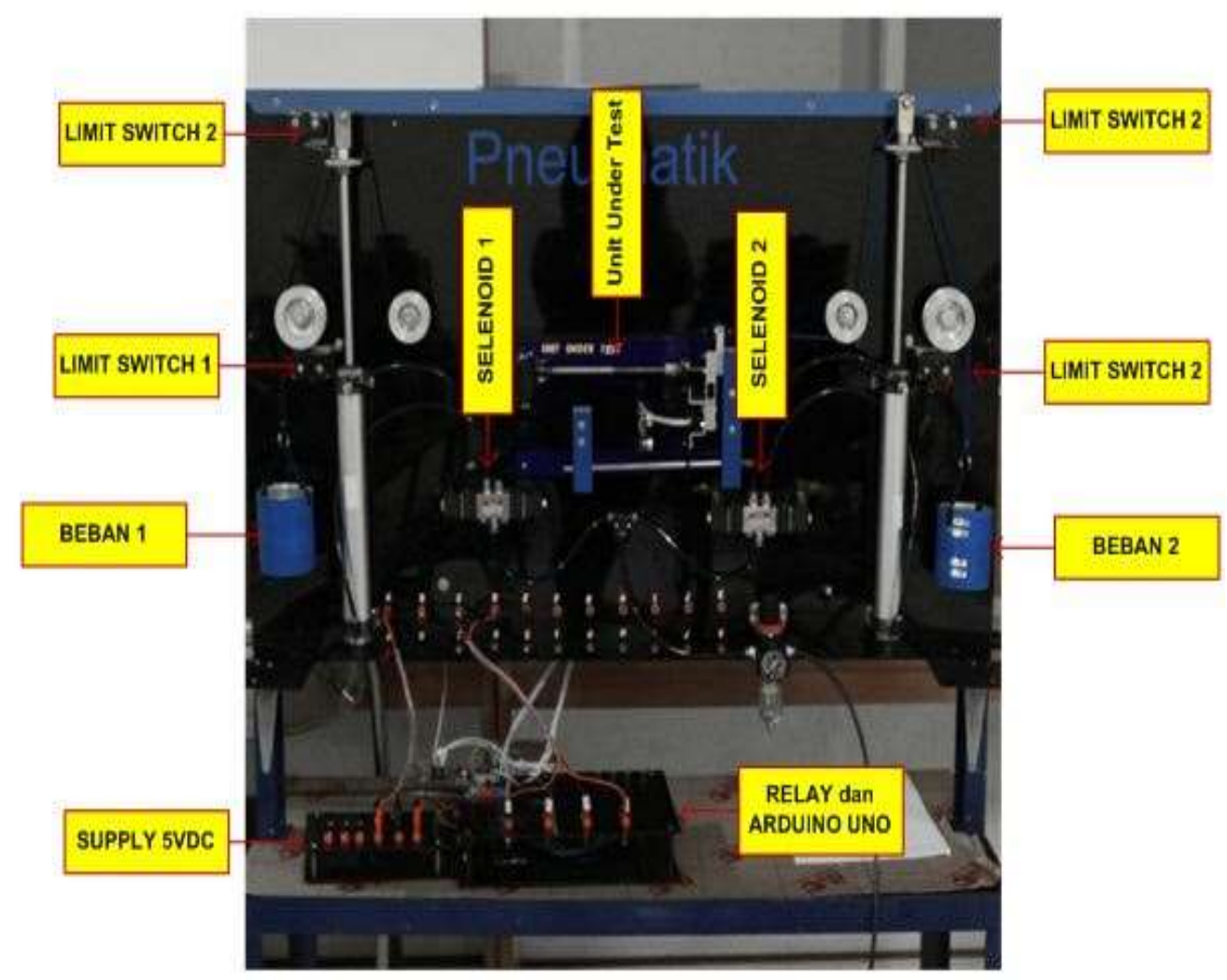

Gambar 3. Realisasi perangkat keras alat uji flight control actuator

\subsection{Perancangan dan Realisasi Data Acquisition System}

Pembuatan program dengan Labview ini bertujuan untuk menampilkan akusisi data dari arduino uno ke komputer yang berupa data jarak dan beban, ditampilkan berupa grafik jarak dan beban. Pengiriman data dari arduino uno ke komputer menggunakan kabel USB. Berikut beberapa tahapan untuk pembuatan akuisisi data alat uji flight control actuator:

1. Perancangan interface arduino dengan Labview.

2. Perancangan akusisi data sensor ping dan load cell.

3. Perancangan tampilan grafik sensor ping dan load cell.

4. Perancangan keseluruhan akusisi data alat uji flight control actuator.

\subsection{Perancangan interface arduino dengan Labview.}

Pada penelitian ini data sistem akuisisi data menggunakan komunikasi serial sebagai jalur penghubung antara hardware dengan software dikarenakan dalam penggunaannya lebih sederhana dibanding dengan komunikasi paralel. Apalagi kebanyakan komputer (laptop) sekarang ini sudah tidak memiliki port paralel, hanya port USB serial saja. Begitu pula dari sisi hardware, dengan adanya mikrokontroler, hampir semua mikrokontroler juga telah mendukung komunikasi serial. Salah satunya komunikasi serial untuk sistem data akuisisi sederhana.

\section{Perancangan dan Realisasi Perangkat Lunak (Software)}

Algoritma bertujuan untuk mempermudah langkah-langkah pengerjaan dalam pembuatan suatu program, sehingga program yang dibuat sesuai dengan hasil yang diharapkan. Berikut adalah algoritma untuk interface arduino dengan labview :

1. Start.

2. Mencari jalur koneksi port PC yang terhubung dengan arduino uno.

3. Jika port terbaca pada tampilan Labview maka pilih port yang terhubung dengan arduino uno. 
4. Setting baud rate sesuai dengan program yang terdapat pada pengaturan program arduino uno.

5. Memberikan perintah penampilan data.

6. Finish.

Berdasarkan algoritma tersebut, maka flowchart akuisisi data interface arduino dengan Labview dapat diuraikan seperti Gambar 4.

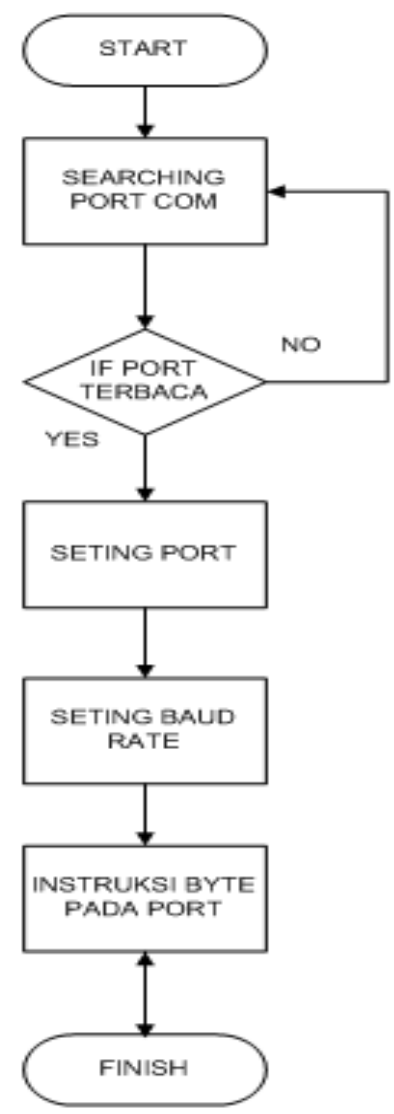

Gambar 4. Flowchart akuisisi data interface arduino dengan labview

Berdasarkan algoritma dan flowchart di atas penulis membuat program interface komunikasi serial pada Labview, berikut program interface komunikasi serial dengan labview. Tampilan blok diagram interface arduino dengan Labview seperti Gambar 5.

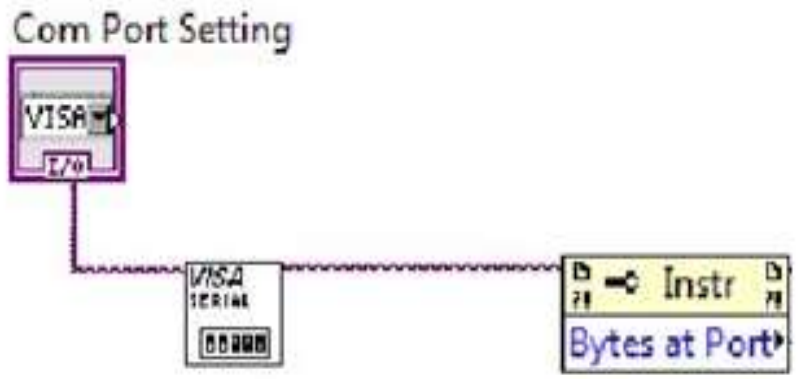

Gambar 5. Blok diagram komunikasi serial pada Labview

Tampilan PC interface arduino dengan labview dapat dilihat pada Gambar 6. 


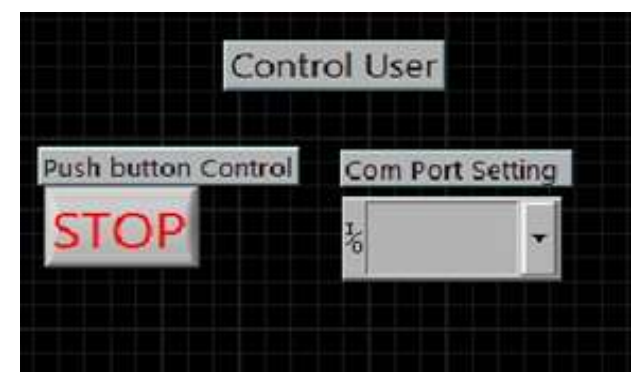

Gambar 6. Tampilan PC interface arduino dengan Labview

\subsection{Perancangan akusisi data sensor ping dan load cell.}

Perancangan akuisisi data pada alat uji flight control actuator ini menggunakan 2 sensor diantaranya :

1. Sensor Load Cell

2. Sensor Ping

Pada akusisi alat uji flight control actuator ini load cell berfungsi untuk mengetahui beban yang di terima oleh aktuator. Berikut algoritma dan flowchart perangkat lunak (software):

\subsubsection{Perancangan dan Realisasi Perangkat Lunak (Software)}

Algoritma bertujuan untuk mempermudah langkah-langkah pengerjaan dalam pembuatan suatu program, sehingga program yang dibuat sesuai dengan hasil yang diharapkan. Berikut adalah algoritma untuk interface arduino dengan Labview :

1. Start

2. Pembacaan sensor ping dan load cell.

3. Kirim data hasil pembacaan sensor ping dan load cell ke arduino uno.

4. Proses data sensor ping dan load cell hingga menjadi data digital di arduino uno.

5. Tampilkan kedua data sensor ke PC dengan tampilan labview yang telah diprogram terlebih dahulu.

6. selesai

Berdasarkan algoritma tersebut, maka flowchart akuisisi data sensor ping dan load cell dapat ditunjukkan seperti Gambar 7.

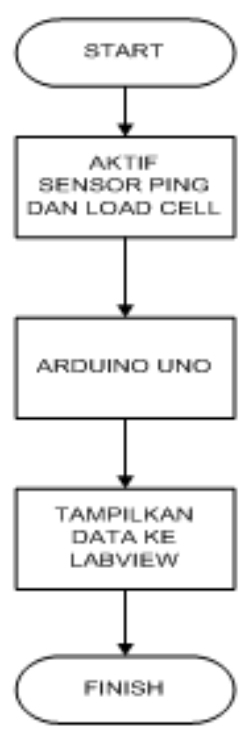

Gambar 7. Flowchart akusisi data sensor ping dan load cell 
Berdasarkan algoritma dan flowchart diatas penulis membuat program akuisisi data sensor ping dan load cell dengan Labview. Berikut tampilan blok diagram akuisisi data dengan Labview sensor ping dan Labview.

\subsubsection{Blok diagram Sensor ping :}

Fungsi dari sensor ping ini adalah untuk mengetahui jarak dari pergerakan aktuator. Berikut tampilan blok diagram akuisisi data sensor ping dengan Labview seperti Gambar 8.

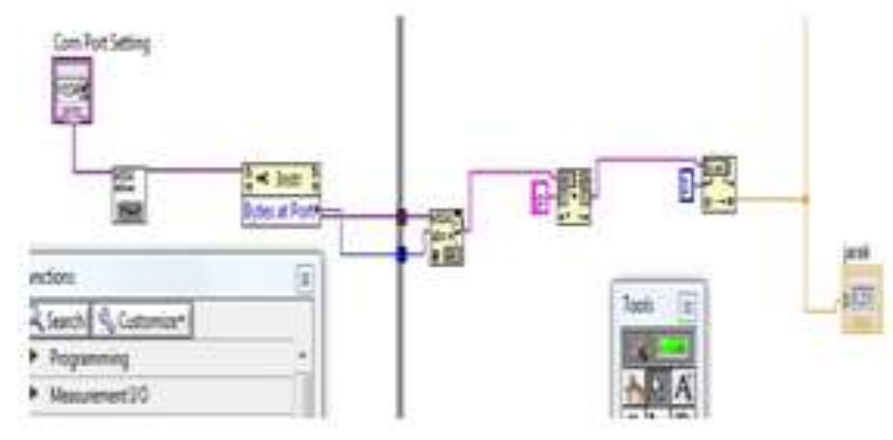

Gambar 8. Blok diagram akuisisi data sensor ping pada Labview

\subsubsection{Blok diagram Sensor load cell.}

Fungsi dari sensor load cell ini adalah untuk mengetahui berat beban yang diterima oleh aktuator yang berupa motor servo. Berikut tampilan blok akuisisi data sensor load cell dengan Labview seperti Gambar 9.

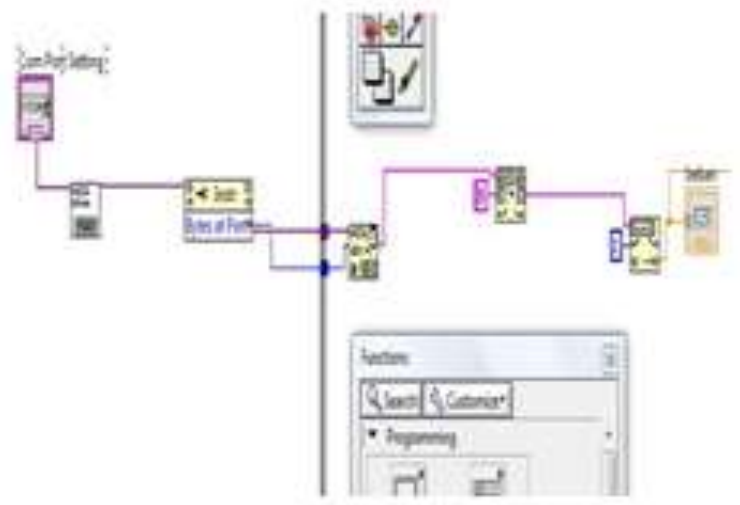

Gambar 9. Blok diagram data akuisisi sensor load cell pada Labview

\subsubsection{Tampilan akuisisi data dengan Labview}

Tampilan PC akuisisi data sensor ping dan load cell dengan labview dapat dilihat pada Gambar 10 dan 11.

a. Sensor ping.

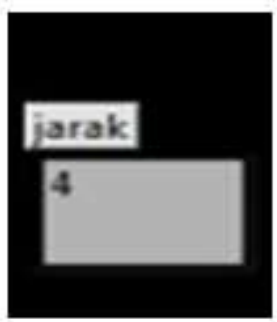

Gambar 10. Hasil akuisisi data sensor ping 
b. Sensor load cell

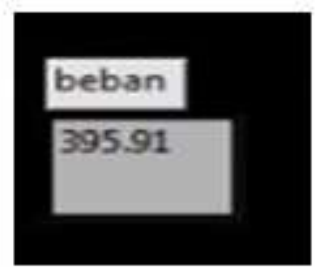

Gambar 11. Hasil akuisisi data sensor load cell

\subsection{Perancangan tampilan grafik sensor ping dan load cell.}

Pada akusisi data pada alat uji flight control ini penulis diminta untuk menampilkan data dalam bentuk grafik dari sensor load cell dan ping yang digunakan terhadap waktu.

\subsubsection{Blok Diagram Grafik Sensor Ping Pada LabView}

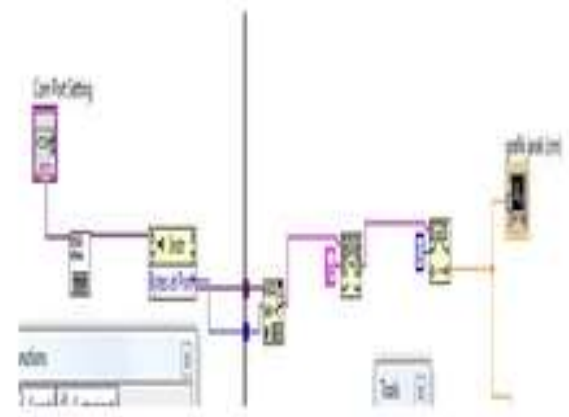

Gambar 12. Blok diagram data akuisisi sensor ping dalam bentuk grafik pada Labview

Tampilan blok diagram grafik sensor load cell pada LabView seperti dapat dilihat pada Gambar 13.

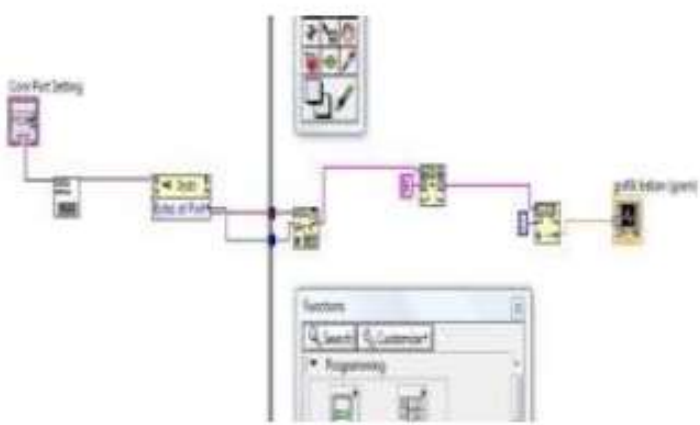

Gambar 13. Blok diagram data akuisisi load cell dalam bentuk grafik pada Labview

\subsection{Perancangan keseluruhan akuisisi data alat uji flight control actuator}

Pada perancangan keseluruhan akusisi data alat uji flight control actuator dengan menggabungkan dari perancangan interface arduino dengan Labview, akuisisi data sensor dengan labview dan tampilan grafik sensor ping dan load cell dengan Labview. Berikut algoritma dan flowchart perangkat lunak (software).

\section{Perancangan dan Realisasi Perangkat Lunak (Software)}

Algoritma bertujuan untuk mempermudah langkah-langkah pengerjaan dalam pembuatan suatu program, sehingga program yang dibuat sesuai dengan hasil yang diharapkan. Berikut adalah algoritma untuk interface arduino dengan Labview :

1. Start.

2. Pengaturan port com yang terhubung dengan arduino uno. 
3. Tampilkan data berupa data satuan jarak dan berat.

4. Tampilkan data sensor jarak dan beban dalam bentuk grafik.

5. Finish.

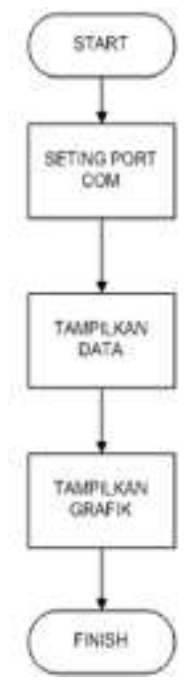

Gambar 14. Realisasi alat uji flight control actuator

Berdasarkan algoritma dan flowchart diatas penulis membuat program akuisisi data alat uji flight control actuator pesawat. Berikut program akuisisi data alat uji flight control actuator dengan Labview :

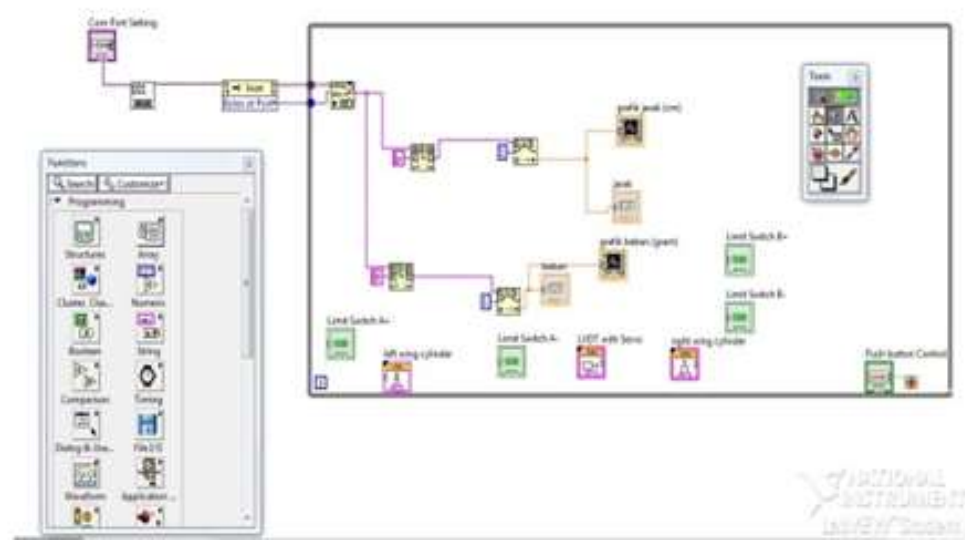

Gambar 15. Blok diagram pemrograman akuisisi data alat uji flight control actuator dengan Labview

Tampilan PC interface arduino dengan Labview dapat dilihat pada Gambar 16. 


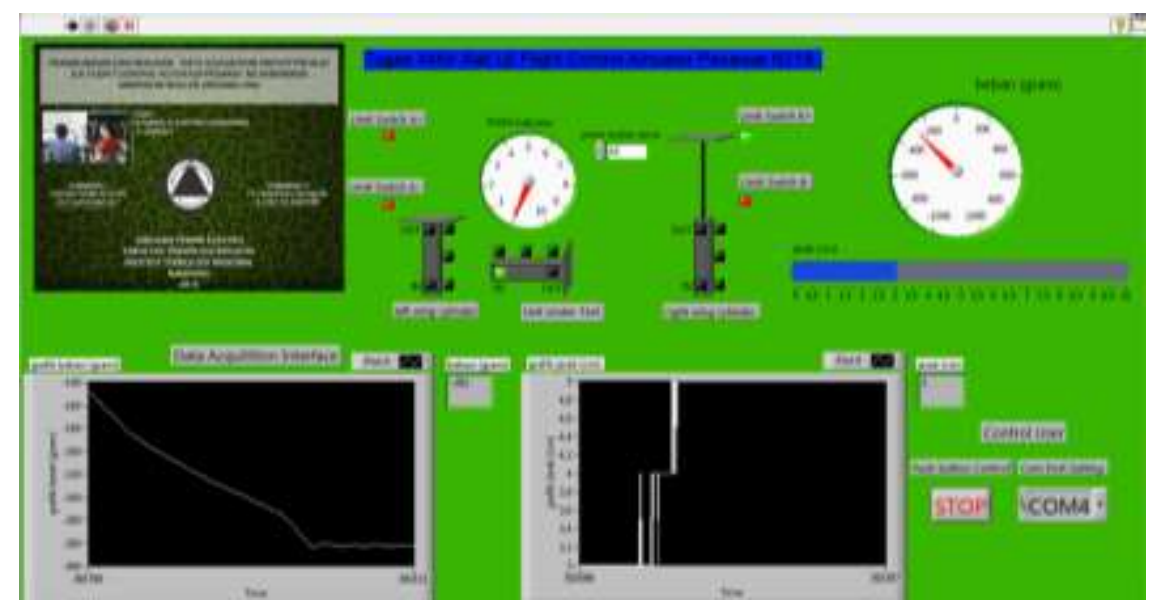

Gambar 16. Tampilan PC interface arduino dengan Labview

\section{PENGUJIAN ALAT DATA ACQUISITION SYSTEM (DAQ)}

Pengujian dan analisis yang dilakukan pada perangkat lunak (software) meliputi beberapa komponen, yaitu :

1. Pengujian komunikasi serial hardware dengan software.

2. Pengujian visual monitor DAQ Labview dengan integrasi sensor ping.

3. Pengujian visual grafik DAQ Labview dengan integrasi sensor load cell.

4. Pengujian software sistem secara keseluruhan.

\subsection{Pengujian komunikasi serial hardware dengan software}

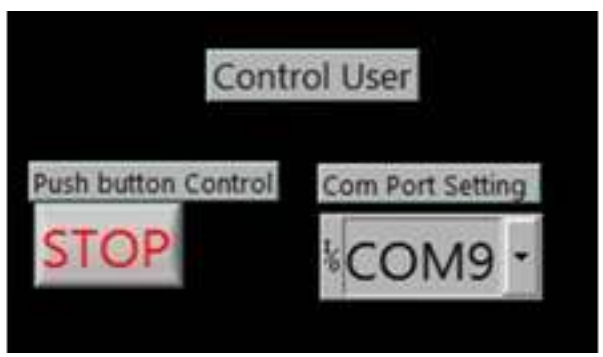

Gambar 17. Tampilan pengujian pada software Labview

Gambar 17 memperlihatkan pengujian komunikasi USB bahwa pengaturan port harus mengetahui terlebih dahulu driver arduino uno telah terpasang pada PC dengan menghubungkan antara arduino uno dengan PC menggunakan kabel USB serial, apabila arduino telah terhubung dengan PC maka dapat diketahui port yang dipakai sehingga terbaca port arduino yang ter install pada PC. Port yang digunakan berada pada port 9.

\subsection{Pengujian Dan Analisis Visual Monitor DAQ Labview dengan Integrasi Sensor Ping}

Pada pengujian visual monitor DAQ Labview dengan integrasi sensor ping dilakukan dengan pengambilan data sensor yang dikirim ke arduino yang ditampilkan melalui pc dengan bantuan software Labview yang telah diprogram terlebih dahulu. Hasil pengujian visual monitor DAQ Labview dengan integrasi sensor ping dapat dilihat pada Gambar 18. 


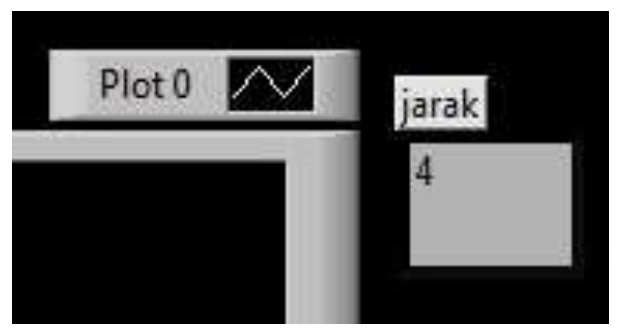

Gambar 18. Tampilan visual nilai sensor ping DAQ pada Labview

Seperti yang terlihat pada Gambar 18 data acquisition antara hardware dengan software Labview telah berhasil terhubung secara automatis melalui komunikasi serial menggunakan USB sehingga data yang ditangkap oleh sensor ping dapat diakuisisi untuk disimpan dan ditampilkan pada layar monitor PC yang diatur oleh control user operator.

\subsection{Pengujian Dan Analisis Visual Monitor DAQ Labview Dengan Integrasi Sensor Load Cell.}

Pengujian dan analisis visual monitor DAQ Labview dengan integrasi sensor load cell dilakukan dengan pengambilan data sensor yang dikirim ke arduino yang ditampilkan melalui pc dengan bantuan software Labview yang telah diprogram terlebih dahulu. Hasil pengujian visual monitor DAQ Labview dengan integrasi sensor load cell dapat dilihat pada Gambar 19.

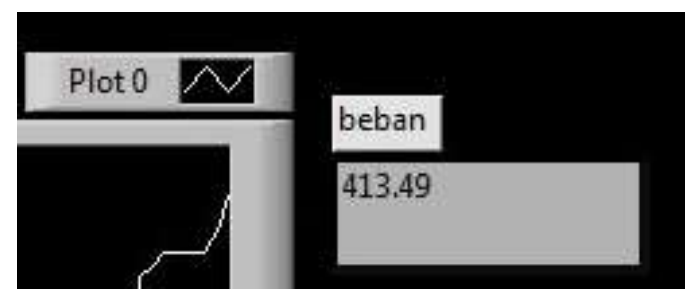

Gambar 19. tampilan visual nilai sensor load cell DAQ pada Labview

Seperti yang terlihat pada Gambar 19 data acquisition antara hardware dengan software Labview telah berhasil terhubung secara automatis melalui komunikasi serial menggunakan USB sehingga data yang ditangkap oleh sensor load cell dapat diakuisisi untuk disimpan dan ditampilkan pada layar monitor PC yang diatur oleh control user operator.

\subsection{Pengujian Dan Analisis Sistem DAQ Secara Keseluruhan}

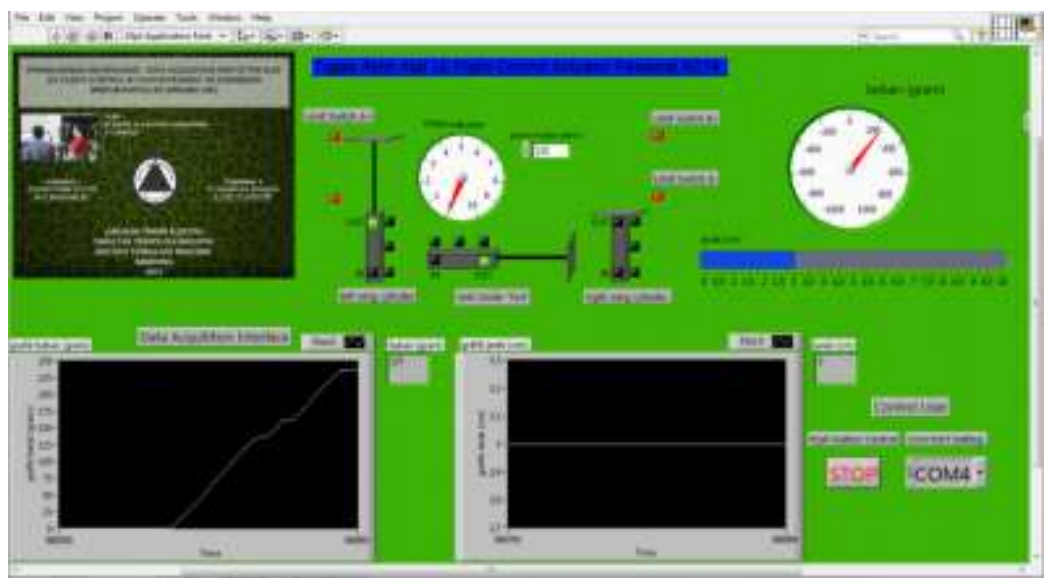

Gambar 20. Pengujian dan analisis sistem DAQ secara keseluruhan 
Gambar 20 menunjukkan bahwa pengujian keseluruhan sistem DAQ menggunakan software Labview telah terintegrasi dengan baik seperti yang terlihat pada Gambar 20 Data acquisition antara hardware dengan software Labview, dari pengujian yang dilakukan diperoleh analisis yaitu sistem DAQ yang dilakukan ternyata tidak berjalan secara real time dengan stabil. Hal ini dikarenakan media perantara DAQ yaitu mikrokontroller arduino uno tidak dapat secara bersamaan mengambil data dan memerintah data, dikarenakan media untuk mengkontrol juga untuk mengakuisisi data dilakukan oleh 1 kontroller yang sama yaitu mikrokontroller arduino uno. Sistem akan berubah menjadi tidak real time ketika saat nilai data akuisisi yang akan terinput dari mikro arduino uno akan terhalang oleh program utama yang terdapat pada mikro arduino uno yang sedang memproses untuk mengkontrol sistem kerja keseluruhan dari hardware yang memberi dan menerima input untuk mengkontrol sensor ping, loadcell, motor servo, dan solenoid valve.

\section{KESIMPULAN}

Berdasarkan hasil perancangan, realisasi dan pengujian terhadap alat uji DAQ flight control menggunakan arduino uno berbasis atmega328 yang telah dilakukan, maka dapat diambil beberapa kesimpulan sebagai berikut.

1. Integrasi antara perangkat keras (hardware) dengan perangkat lunak (software) alat uji flight control actuator telah bekerja sesuai spesifikasi sistem yang diinginkan, seperti yang terlihat pada hasil pengujian sistem.

2. Proses pengakuisisian data untuk beban dan jarak pada sensor ping dan sensor load cell sesuai dengan data real yang dihasilkan oleh hardware.

3. Sistem DAQ yang dilakukan ternyata tidak berjalan secara real time dengan stabil. Hal ini dikarenakan media perantara DAQ yaitu mikrokontroller arduino uno tidak dapat secara bersamaan mengambil data dan memerintah data, dikarenakan media untuk mengkontrol juga untuk mengakuisisi data dilakukan oleh 1 kontroller yang sama yaitu mikrokontroller arduino uno. Sistem akuisisi data akan berubah menjadi tidak real time ketika saat nilai data akuisisi yang akan terinput dari mikro Arduino uno akan terhalang oleh program utama yang terdapat pada mikro Arduino uno yang sedang memproses untuk mengkontrol system kerja keseluruhan dari hardware yang berupa memberi dan menerima input untuk mengkontrol sensor ping, load cell, motor servo, dan solenoid valve.

4. Integrasi untuk menghubungkan hardware alat uji flight control actuator ke PC/laptop telah berhasil sehingga data hardware tersebut dapat ditampilkan pada PC menggunakan software Labview dengan mengatur com port communication pada program Labview.

\section{Daftar Pustaka:}

1. 2013.Data Acquisition System (DAS atau DAQ). [Online] Diakses pada tanggal 2 Juni 2015 dari http://jalansurganya.blogspot.com/2013/09/data-acquisition-systemdas-atau-daq.html.

2. . 2011. Airbus Flight Control System. [Online] Diakses pada 1 Juni 2015 dari http://idrus-informasi.blogspot.com.

3. 2015. Flight Control Comercial Aircraft Solutions. [Online] Diakses pada 30 April 2015 dari http://www.baesystems-ps.com.

4. Kusanto, Didik. 2010. Perancangan Sistem Akuisisi Data Sebagai Alternatif Modul DAQ LabView Menggunakan Mikrokontroler ATmega8535. Surabaya: Didik Publisher.

5. Susana, Ratna. 2015. Wireless Sensor Network Prototype Sebagai Fire Detector Menggunakan Arduino Uno. Jurnal Elektro Telekomunikasi Terapan (JETT) Juli 2015 pp 53 - 60

6. Wenda, K. R. 2008. Analisis data kecelakaan dan kegagalan system rudder boing 737. Bandung:Wenda Publisher.

7. 2015. Main Software. [Online] Diakses pada 2 Mei 2015 dari http://www.arduino.cc/en/Main/Software. 